\title{
IDENTIFIKASI PERMAINAN DAN OLAHRAGA TRADISIONAL KABUPATEN GORONTALO
}

\author{
Hartono Hadjarati ${ }^{1}$, Arief Ibnu Haryanto ${ }^{2}$ \\ ${ }^{1}$ Jurusan Pendidikan Kepelatihan Olahraga, Fakultas Olahraga dan Kesehatan, Universitas \\ Negeri Gorontalo \\ 2Jurusan IImu Keolahragaan, Fakultas Keguruan dan IImu Pendidikan, Universitas \\ Muhammadiyah Gorontalo \\ Email : hartonohadjarati@ung.ac.id , ariefibnu67@gmail.com
}

\begin{abstract}
ABSTRAK
Penelitian ini bertujuan untuk mengidentifikasi apa saja permainan dan juga olahraga tradisional yang ada di Kabupaten Gorontalo. Penelitian ini merupakan penelitian kualitatif dengan metode observasi, wawancara, dokumentasi, triangulasi atau gabungan yang menggunakan istrumen kuisioner dalam pengumpulan data. Objek dalam penelitian ini adalah beberapa tokoh budaya setempat yang ada di Kabupaten Gorontalo. Adapun temuan dari penelitian ini ada beberapa jenis permainan dan olahraga tradisional di Kabupaten Gorontalo yaitu Beladiri Langga, Beladiri Longgo, Palapudu, Kalari, Neka, Tenggedi Buau, Tenggedi Wawohu, Cur-Cur Pal, Ponti, Kainje, Patumbu, Lompat Tali, Benteng-Benteng, Koba-Koba, Alanggaya Bulia. Hal ini membuktikan bahwa masih banyak jenis permainan dan olahraga tradisional di Kabupaten Gorontalo yang perlu mendapatkan apresiasi positif dari Masyarakat dan Pemerintah sehingga tidak tergerus oleh jenis permainan yang menggunakan sistem online.
\end{abstract}

Kata Kunci: Permainan Tradisional, Olahraga Tradisional, Kabupaten Gorontalo

\begin{abstract}
This study aims to identify what games and traditional sports exist in Gorontalo District. This research is a qualitative research using observation, interview, documentation, triangulation or combination methods that use a questionnaire instrument in data collection. The objects in this study are several local cultural figures in Gorontalo District. The findings of this study are that there are several types of games and traditional sports in Gorontalo District, namely Beladiri Langga, Beladiri Longgo, Palapudu, Kalari, Neka, Tenggedi Buau, Tenggedi Wawohu, Cur-Cur Pal, Ponti, Kainje, Patumbu, Lompat Tali, Benteng-Benteng, Koba-Koba, Alanggaya Bulia. This proves that there are still many types of games and traditional sports in Gorontalo District that need to get positive appreciation from the community and government so they are not eroded by the types of games that use an online system.
\end{abstract}

Keywords: Traditional Games, Traditional Sports, Gorontalo District 
Jurnal IImu Keolahragaan Undiksha

p-ISSN : 2613-9693 | e-ISSN : 2613-9685

Volume 8 Nomor 3 Tahun 2020

\section{PENDAHULUAN}

Permainan dan olahraga tradisional adalah budaya yang di wariskan oleh nenek moyang pada zaman dahulu dan sangatlah diminati sebelum game online masuk ke Indonesia. Permainan dan olahraga tradisional ini menggunakan alat seadanya yang dapat banyak ditemukan di sekitaran daerah masing-masing. Perlunya suatu regenerasi dan pengenalan sebuah permainan tradisional maupun olahraga tradisional, sangatlah penting dalam upaya pembatasan dalam hal penggunaan gameonline atau gadget (Nadjamuddin, 2016).

Permainan dan olahraga tradisional, seringkali mengandung unsur kompetitif dalam setiap penerapan, akantetapi hal ini dapat meningkatkan unsur sportifitas para pemainnya (Nørgaard, 2009). Maka dari itu, permainan maupun olahraga tradisional akan memperkuat karakter seseorang (Yudiwinata \& Handoyo, 2014) dan erat dengan perkembangan intelektual, sosial, serta karakter anak (Hanief \& Sugito, 2015). Permainan tradisional bisa digunakan sebagai terapi anak, dalam permainan tersebut jiwa anak terlihat secara penuh, juga menyehatkan badan sebagai latihan fisik (Nuriman et al., 2016) dan bisa juga di katakan permainan tradisional adalah olahraga karena semua permaianan memerlukan gerak badan yang lebih, permainan tradisional sebenarnya sangat baik untuk melatih pisikologis dan mental anak yang sedang mengalami masa-masa pembentukan diri.

Permainan tradisional juga dapat melatih kemampun sosial para pemainnya. Inilah yang membedakan permainan tradisional dengan permainan modern. Pada dasarnya, permainan dan olahraga tradisional yang ada di Indonesia memiliki filosofi-filosofi kebersamaan yang akan mengedepankan aspek belajar sambil bermain (Nur, 2013) yang akan turut menstimulasi perkembangan motorik (Efendi, 2015). Pada umumnya, permainan tradisional adalah permainan yang membutuhkan lebih dari satu pemain. Hal ini berbeda dengan permainan modern. Kemampuan sosial anak tidak terlalu di pentingkan dalam permainan modern ini yang lebih ke individu dimana anak-anak dapat bermain sendiri tanpa kehadiran temantemannya (Syahran, 2015).

Meskipun permainan tradisional sudah sangat jarang dimainkan, masih ada sebagian orang di Indonesia di daerah-daerah terpencil khususnya yang ada di Kabupaten Gorontalo Provinsi Gorontalo masih memainakan permainan tradisional meskipun juga sudah mulai tergerus oleh permainan modern. Kabupaten Gorontalo sendiri merupakan sebuah Kabupaten yang terletak di Provinsi Gorontalo yang mempunyai luas sekitar 2.125,47 $\mathrm{km}^{2}$ dengan jumlah penduduk 374.682 jiwa (A'yun \& Pribadi, 2020).

Penelitian sebelumnya oleh Nadjamuddin pada tahun 2016 yang berjudul Membangun karakter anak lewat permainan tradisional daerah Gorontalo belum merepresentasikan permainan dan olahraga tradisional apa saja yang ada di Kabupaten Gorontalo. Pentingnya penelitian ini guna sebagai langkah awal penelitian dasar untuk mengetahui apa sajakah permainan dan juga olahraga tradisional yang berada di Kabupaten Gorontalo.

Adapun tujuan dari penelitian ini yaitu untuk mengidentifikasi apa saja permainan dan juga olahraga tradisional yang ada di Kabupaten Gorontalo. 
Jurnal IImu Keolahragaan Undiksha

p-ISSN : 2613-9693 | e-ISSN : 2613-9685

Volume 8 Nomor 3 Tahun 2020

\section{METODE PENELITIAN}

Pendekatan yang digunakan dalam penelitian ini adalah pendekatan kualitatif. Penelitian ini dilakukan di Kabupaten Gorontalo.

\section{Objek Penelitian}

Adapun objek dari penelitian ini meliputi anak-anak dan tokoh budaya setempat yang ada di Kabupaten Gorontalo.

\section{Instrumen Pengumpulan Data}

Adapun teknik penelitian yang digunakan dalam proses pengumpulan data adalah dengan observasi, wawancara, dokumentasi, triangulasi atau gabungan (Sugiyono, 2015).

\section{Observasi}

Observasi pada penelitian ini menggunakan observasi partisipatif yang digolongkan menjadi partisipasi pasif. Partisipasi pasif sendiri, peneliti datang di tempat kegiatan orang yang akan diamati, tetapi tidak ikut terlibat dalam kegiatan tersebut (Sugiyono, 2015).

Proses observasi pada penelitian ini, peneliti dapat mengamati situasisituasi yang ada di lapangan dengan mencatat apa-apa yang dianggap penting guna menunjang terhadap tujuan penelitian. Pada saat proses observasi ini, peneliti ditemani oleh seorang dari warga stempat yang merupakan tokoh masyarakat Kabupaten Gorontalo. Observasi ini memberikan kemudahan terutama dalam hal memperoleh data di lapangan.

\section{Wawancara \\ Wawancara digunakan sebagai teknik pengumpulan data apabila peneliti ingin melakukan studi pendahuluan untuk menemukan permasalahan yang harus diteliti, tetapi juga apabila peneliti ingin}

mengetahui hal-hal dari responden yang lebih mendalam. Teknik pengumpulan data ini mendasarkan diri pada laporan tentang diri sendiri atau self-report, atau setidak-tidaknya pada pengetahuan dan atau keyakinan pribadi (Sugiyono, 2015).

Proses wawancara pada penelitian ini didampingi oleh tokoh masyarakat Kabupaten Gorontalo yang kemudian peneliti mewawancara satu per satu narasumber.

\section{Dokumentasi}

Dokumentasi merupakan catatan peristiwa yang sudah berlalu. Dokumentasi bisa berbentuk tulisan, gambar, atau karya-karya monumental dari seseorang (Sugiyono, 2015).

Dalam penelitian ini, dokumentasi berbentuk tulisanlah yang peneliti pilih, hal ini dikarenakan beberapa hal termasuk pandemi Covid-19 yang menyebabkan peneliti tidak melakukan bentuk dokumentasi berupa hal yang lainnya.

\section{Triangulasi atau Gabungan}

Triangulasi atau gabungan merupakan suatu teknik pengumpulan. data yang bersifat menggabungkan dari berbagai teknik pengumpulan data yang telah ada (Sugiyono, 2015).

Penelitian ini menggunakan kuisioner untuk satu macam permainan olahraga tradisional. Berikut ini tabel kuisionernya: 
Tabel 1. Identitas Umum Permainan Olahraga Tradisional

Nama Permainan olahraga Tradisional

Periode Waktu di mainkan

Peraturan Permainan

\begin{tabular}{ll}
\hline Etnis yang melaksanakan & Kab. Gorontalo \\
\hline Deskripsi lokasi & -
\end{tabular}

\begin{tabular}{ll}
\hline Perlengkapan permainan tradisional & - \\
\hline Frekuansi pelaksanaan saat ini (pilih salah satu) & (sering) (jarang) \\
\hline Jumlah orang yang memainkan & - \\
\hline
\end{tabular}

Catatan pengisian:

1. Satu kuensioner ini hanya untuk 1 (satu) objek Olahraga Tradisional.

2. Jika terdapat lebih dari satu Olahraga Tradisional di Kabupaten/Kota, diharapkan untuk memperbanyak
3. kuisioner ini sesuai dengan banyaknya Olahraga Tradisional yang teridentifikasi diwilayah tersebut.

4. Untuk memudahkan pengisian, diharapkan untuk dapat membaca definisi operasional yang terlampir dipetunjuk teknis.

Tabel 2. Identifikasi Lembaga Sarana dan Prasarana Objek Permainan Olahraga Tadisional

Daftar Organisasi yang lingkup kegiatannya berhubungan dengan objek Olahraga Tradisional tersebut. Jika terdapat lebih dari satu organisasi dipisahkan dengan tanda titik koma (;)

Nama Organisasi :

Ruang terbuka, baik lapangan terbuka maupun gedung/bangsal sekolah

Sarpras masyarakat Ruangan rumah atau halaman rumah

Sarpras pemerintah

Bangsal sekolah

Tabel 3. Identifikasi Produk Hukum Olahraga Tradisional

\begin{tabular}{llll}
\hline Adakah peraturan khusus di tingkat & 1. Ya \\
kabupaten/kota yang mengatur tentang Olahraga & 2. Tidak
\end{tabular}

Tradisional yang bersangkutan?

Jika Ya, sebutkan peraturan yang mneyangkut tentang hal tersebut

Nama peraturan $\quad$ Bentuk peraturan (Perda, SK DII) 
Catatan pengsisian:

Tambahkan baris apabila terdapat lebih dari satu peraturan lampirkan kedalam produk hukum aplikasi.

\section{Teknik Analisis Data}

Analisis data dalam penelitian berlangsung selama sebelum memasuki lapangan, selama di lapangan dan setelah selesai di lapangan (Sugiyono, 2015).

Penelitian ini menggunakan teknik analisis data Miles and Huberman model interaktif (Sugiono, 2015). Adapun modelnya sebagai berikut:

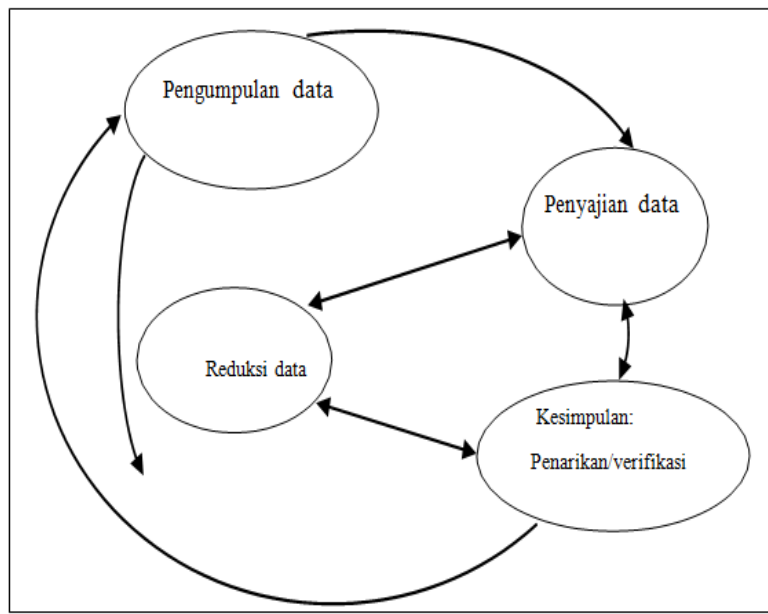

Gambar 1. Komponen dalam Analisis Data Miles and Huberman Model Interaktif

\section{HASIL DAN PEMBAHASAN}

\section{Hasil Penelitian}

Setelah Peneliti melakukan penelitian ke berbagai daerah yang berada di Kabupaten Gorontalo dengan memperhatikan protokol kesehatan demi memutus mata rantai penyebaran virus covid-19, tahap perkenalan pada Masyarakat atau Narasumber yang akan di teliti dan berdasarkan hasil adalah sebagai berikut:

\section{Beladiri Langga}

Langga merupakan seni beladiri tradisional masyarakat Gorontalo, seni beladiri ini tidak di gunakan untuk membunuh, melainkan untuk menjaga diri dan melumpuhkan lawan, tetapi tidak di wajibkan menimbulkan korban jiwa.

\section{Beladiri Longgo}

Beladiri Longgo merupakan beladiri khas Gorontalo yang tidak berbeda jauh dengan Langga, yang membedakannya adalah beladiri ini menggunakan senjata tajam atau sejenis parang sebagai alat untuk melindungi diri. Seni beladiri Longgo sangat unik karena gerakannya berkaitan erat dengan gerakan seharihari, seni beladiri tradisional Gorontalo yang diperkaya dengan budaya gerak, yang berkaitan dengan upacara adat Istiadat Daerah Gorontalo.

\section{Permainan Palapudu}

Palapudu adalah permaianan tradisional Gorontalo yang dominan dimainkan oleh anak Laki-laki, Palapudu ini salah satu permainan tradisional yang di mainkan di Daerah Kabupaten Gorontalo secara individu maupun berkelompok karena permainan ini mirip seperti senapan meskipun terbuat dari bambu yang masih muda, jadi tak heran dikalau anak laki-laki dominan memainakan permaianan ini dan digunakan sebagai media atau alat perang-perangan.

\section{Permainan Kalari}

Permainan Kalari adalah sebuah permaianan tradisional yang di mainkan secara berkelompok atau secara tim di masing-masing tim terdiri dari tiga sampai lima orang inti dari permaianan ini adalah menghadang lawan agar tidak lolos melewati garis atau baris terakhir secara bolak-balik.

Permaianan ini biasanya dimainkan di tanah lapang atau lapangan terbuka, untuk membuat area atau lapangan permainan biasanya menggunakan kapur atau garis seadanya dengan membetuk persegi panjang yang terbagi menjadi enam bagian dan disetiap garis di jaga 
oleh masing-masing anggota dari tim yang bertugas untuk menghadang.

\section{Permainan Neka}

Permainan Neka adalah sebuah permaian yang digemari oleh anak-anak bahkan sebagian remaja yang ada di Kabupaten Gorontalo. Jenis permainan ini hampir sama persis dengan kelereng yang membedakanya adalah cara memainkan permainan ini dengan menggunakan sejenis nonok (benda plastik) yang besar berbentuk seperti kelereng dan menggunakan tiga lobang yang di buat di atas permukaan tanah. Permaianan ini bisa di mainkan secara individu maupun kelompok permaian ini tidak membatasi jumlah pemain disetiap tim memiliki jumlah pemain yang sama atau seimbang.

\section{Permainan Tenggedi Buau}

Permainan Tenggedi Buau yaitu menggunakan dua tempurung (Buau) kelapa kering yang akan dikaitkan dengan menggunakan tali, dalam permainan ini pemain sudah tidak perlu melubangi tempurung kelapa jika di setiap tempurung sudah memiliki lubang dengan sendrinya sesudah itu pemain harus memasukan tali ke lubang tempurung yang suda ada atau yang telah dibuat dengan sendirinya, masing-masing ujung tali yang sudah masuk kedalam tempurung lalu di ikat dengan sebuah kayu agar supaya tali tidak mudah lepas dari tempurung pada saat pemain memainkannya. Kedua tempurung yang sudah diikat dengan tali akan menjadi pijakan kaki pemain, pada saat melakukan pijakan pemain harus memegang tali untuk menjaga keseimbangan pada saat berjalan,

\section{Permainan Tenggedi Wawohu}

Tenggedi wawohu adalah jenis permainan yang terbuat dari bambu (Talilo) Pertama-tama mencari bambu yang cukup kuat untuk menopang berat badan dari pemain, selanjutnya potong bambu menjadi dua bagian dengan ukuran yang sama panjang. Lubangi kedua bambu dengan menggunakan pisau dan gergaji dengan sejajar, setelah selesai di lubangi pasangkan kayu atau tempat pijakan kaki pemain, pastikan kayu yang digunakan sebagai pijakan benar-benar terpasang dengan kuat, permainan ini biasanya di perlombakan pada saat Lebaran Ketupat yang identik dengan adat istiadat yang ada di Kabupaten Gorontalo.

\section{Permainan Cur-Cur Pal}

Cur-Cur Pal yaitu permainan secara berkelompok agar supaya lebih seru dan bisa dimainkan kapan saja, sebelum memainkan permainan sekelompok anakanak atau pemain akan melakukakan suit (Pila-Pila Pimpa). Tujuan dari suit ini untuk mencari pemain yang akan bertugas menjaga base apabila sudah ditentukan, maka pemain lain akan bersembunyi di tempat mana saja kecuali di dalam rumah dan tempat lain yang sudah disepakati bersama apabila dilanggar maka yang melakukan pelanggaran yang akan menggantikan si penjaga base.

Penjaga base akan mencari pemain lain yang bersembunyi, apabila ada yang terlihat oleh penjaga base maka penjaga base akan mengucapkan cur disertai dengan nama si pemain yang bersembunyi. Jika salah dalam penyebutan nama (Sala Sum) maka permainan akan dinyatakan batal dan penjaga base akan menjaga kembali, penjaga base akan menjaga base dengan sebaik mungkin agar tidak ada pemain yang bersembunyi menyentuh base yang di jaganya (Pal). Permainan akan berakhir apabila para pemain suda merasa kecapeaan (Mongolo).

\section{Permainan Ponti}

Permainan Ponti dapat dilakukan perindividu ataupun dengan membentuk tim, tergantung banyaknya pemain yang ikut serta dalam permainan. Apabila 
permainan dimainkan dengan jumlah yang ganjil, maka permainan akan dilakukan perindividu namun apabila jumlah pemain genap, maka permainan akan dimainkan menjadi pertim.

Permaianan akan dimainkan menggunakan batu kecil (Kerikil) sebanyak lima buah dengan satu bolah tenis yang di pantulkan ke lantai pada saat bola memantul maka pemain akan mengambil batu yang berjumblah lima tersebut sesuai dengan urutan, setelah selesai melakukan permainan Ponti sesuai dengan urutan, maka pemain akan melakukan tapis yang akan menentukan poin yang akan di kumpulkan.

\section{Permainan Kainje}

Permainan Kainje yaitu mirip seperti permaianan Kalari yang menggunakan garis gambar di atas permukaan tanah. Permaianan ini biasanya dimainkan oleh anak-anak perempuan pada saat libur sekolah dipagi hari maupun sore hari. Bentuk gambar permainan Kainje ini mirip seperti anak tangga dimana anak-anak akan melompat-lompat dan tidak boleh menyentuh garis yang sudah dibuat. Apabila menyentuh garis, pemain akan diganti dengan pemain lawan dan menunggu pemain lawan akan membuat kesalahan kembali. Jika ada pemain yang bisa melewati tantangan, maka akan di hitung satu poin, dan yang akan menjadi pemenang dalam permaianan ini adalah pemain yang sudah melampaui poin yang telah disepakati.

\section{Permainan Patumbu}

Sebelum memainkan permainan Patumbu, pemain harus menyiapkan karet tangan (Goro). Setelah itu pemain harus membuat tiang untuk menggantung karet tangan dimana tiang ini yang desebut patumbu oleh pemain. Tiang atau tempat untuk menggantung karet tangan terbuat dari Lidi yang telah dimodifikasi. Setelah itu tancapkan patumbu di permukaan tanah. Sebelum bermain, para pemain harus menyepakati batas atau jarak yang akan menjadi jarak tembak, pemaian akan melakukan lemparan gaco yang akan menjadi jarak tembak (Loka). Jarak yang terjauh yang akan menjadi penembak perdana, dan apabila penembak pertama menegenai sasaran pertanda permainan selesai dan akan diulangi kembali.

\section{Permainan Lompat Tali}

Permaianan Lompat Tali ini menjadi perminan yang banyak diminati oleh anak perempuan. Sebelum memulai permainan, pemain akan mengayam karet tangan (Goro) hingga panjang menyerupai tali. Proses penganyaman karet tangan akan dipilih kulitas karet sehingga tidak mudah putus saat akan melakukan lompatan.

Setiap lompatan memiliki tingkatan tersendiri yaitu tingkatan pertama pemain harus memulai lompatan dengan tinggi tali setinggi lutut $(\mathrm{Hu}, \mathrm{u})$, tingkatan kedua yaitu pinggang (Wohuta), tingkatan ketiga yaitu telinga (Bulonga), tingkatan keempat kepala (Lunggongo) tingkatan kelima yaitu satu jengkal dari kepala, tingkatan keenam atau tingkatan terakhir setinggi tangan dari pemain (Ngo ulu,u Londo Lunggongo) dan yang akan menjadi pemenang yaitu pemain yang bisa melewati tingkatatan-tingkatan tersebut tanpa melakukan kesalahan.

\section{Permainan Benteng-Benteng}

Permainan Benteng-Benteng akan mencari lokasi yang luas untuk dijadikan lokasi permainan benteng-benteng ini. Para pemain akan mencari batu atau benda yang lainya yang akan dijadikan benteng. Batu yang sudah didapat akan disejajarkan dan saling berhadapan. Permainan ini akan dimainkan secara berkelompok agar permainan menjadi lebih seru. Jumlah pemain tidak dibatasi, yang penting setiap tim memiliki jumlah yang sama atau seimbang. Sebagai permulaan permainan, ada salah satu dari anggota tim yang akan memancing (Mogarata) anggota tim lawan yang akan 
keluar dari benteng mereka. Apabila ada anggota tim lawan tertangkap akan disandara di lokasi yang berjarak 5 meter dari benteng yang dijaga. Tim lawan akan berusaha melepaskan teman mereka yang disandara dengan cara menyentuh tangan teman. Poin untuk memenangkan permainan, masing-masing tim harus menyentuh benteng lawan agar bisa menghasilakan Poin.

\section{Permainan Koba-Koba}

Permainan Koba-Koba ini merupakan suatu permainan tradisional yang mudah dimainkan karena peralatan yang akan digunakan bisa di temui dimana saja termasuk halaman rumah. Pertama-tama pemain akan menyusun batu bata (Batu Tela) untuk dijadikan sasaran pada saat bermain. Selanjutnya pemain akan membuat batas garis yang disepakati bersama untuk menjadi batas lemparan. Setiap pemain harus menyiapkan alat yang akan digunakan untuk melempar sasaran seperti batu atau kayu yang berukuran kecil (botu wau buahulo). Sebelum melakukan lemparan yang akan menentukan jarak untuk menembak (Loka), penembak pertama akan di ambil dari jarak yang paling jauh menggunakan wayang bergambar yang akan di jadikan sebagai alat taruhannya, dan permainan akan berakhir apabila ada pemain yang sudah mengenai sasaran lemparan yang tersusun dari batu bata tersebut.

\section{Permainan Alanggaya Bulia}

Permainan Alanggaya Bulia merupakan salah satu permainan yang proses pembuatanya membutuhkan waktu yang cukup lama. Sebelum memainkan permainan yang satu ini para pemain harus membuat ranggka (Balanga) menggunakan bambu yang sudah benar-benar kering, bambu yang sudah kering akan diukir menggunakan pisau, belah bambu menjadi dua bagian dan potong sama panjang, haluskan kedua bambu yang telah di potong panjang sehingga mempermudah proses pembuatannya, selanjutnya buatkan rangka tengah alanggaya (Tiluhula), dengan menggunakan bambu yang kuat agar tidak mudah patah pada saat alanggaya jatuh (Mosuporu), dari setiap pemain alanggaya memiliki dua bahkan lebih alanggaya yang akan di sesuaikan dengan kondisi angin, bermain Alanggaya Bulia harus menggunakan nilon pancing sebagai alat untuk menerbangkan Alanggaya Bulia sehingga tidak mudah putus (Mobundo), dan untuk memainkan permainan Alanggaya Bulia yaitu di lapangan yang luas sehingga lebih gampang untuk menerbangkannya

\section{PENUTUP}

\section{Simpulan}

Berdasarkan hasil penelitian dan pembahasan yang diperoleh, maka penelitian identifikasi permainan dan olahraga tradisional di Kabupaten Gorontalo. Menunjukan bahwa Kabupaten Gorontalo memiliki kekayaan permainan dan olahraga tradisional yang beragam dan sudah mengalami proses kulturasi dari budaya suku-suku di Nusantara. Hal ini dibuktikan bahwa beberapa dari permainan tersebut mirip dengan permainan tradisional dari daerah lain yang ada di Nusantara.

Saran

Berdasarkan dari penelitian ini, saran yang dapat diberikan yaitu masyarakat bersama dengan pemerintah perlu memperkenalkan kembali permainan dan olahraga tradisional yang ada di Kabupaten Gorontalo sehingga selain untuk mempopulerkan permainan dan olahraga tradisional Kabupaten Gorontalo, masyarakat akan mempunyai dampak postif dari permainan dan olahraga tradisional tersebut. 


\section{DAFTAR PUSTAKA}

A'yun, M. Q., \& Pribadi, W. (2020). STATISTIK DAERAH KABUPATEN GORONTALO 2020. Badan Pusat Statistik Kabupaten Gorontalo.

Efendi, D. I. (2015). Permainan Tradisional Sebagai Media Stimulasi. Didaktika.

Hanief, Y. N., \& Sugito, S. (2015). Membentuk Gerak Dasar Pada Siswa Sekolah Dasar Melalui Permainan Tradisional. Jurnal SPORTIF : Jurnal Penelitian Pembelajaran.

https://doi.org/10.29407/js_unpgri.v1 i1.575

Nadjamuddin,

A. (2016).

Membangunkarakter anak lewat permainan tradisional daerah Gorontalo. TADBIR: Jurnal Manajemen Pendidikan Islam.

Nørgaard, K. (2009). Traditional games as new games: Towards an educational philosophy of play. Sport, Ethics and Philosophy. https://doi.org/10.1080/1751132090 2982451
Nur, H. (2013). Building children's character through traditional games. Junal Pendidikan Karakter.

Nuriman, R., Kusmaedi, N., \& Yanto, S. (2016). Pengaruh Permainan Olahraga Tradisional Bebentengan terhadap Kemampuan Kelincahan Anak Usia 8-9 Tahun. Jurnal Terapan IImu Keolahragaan. https://doi.org/10.17509/jtikor.v1i1.1 550

Sugiyono. (2015). Metode Penelitian. Metode Penelitian.

Syahran,

$\mathrm{R}$.

(2015). KETERGANTUNGAN ONLINE GAME DAN PENANGANANNYA. Jurnal Psikologi Pendidikan Dan Konseling: Jurnal Kajian Psikologi Pendidikan Dan Bimbingan Konseling. https://doi.org/10.26858/jpkk.v1i1.15 37

Yudiwinata, H. P., \& Handoyo, P. (2014). Permainan Tradisional dalam Budaya dan Perkembangan Anak. Paradigma 